\title{
ANALISIS PERKULIAHAN DARING PADA SEMESTER V PROGRAM STUDI PENDIDIKAN GURU PENDIDIKAN ANAK USIA DINI
}

\author{
Joni ${ }^{1}$, Melvi Lesmana Alim ${ }^{2}$ \\ Program Studi PG-PAUD, Universitas Pahlawan Tuanku Tambusai \\ e-mail : joni1617@gmail.com
}

\begin{abstract}
Abstrak
Perubahan system perkuliahan dari tatap muka menjadi daring yang disebabkan munculnya wabah Covid-19, sedikit banyaknya telah membawa pengaruh cara belajar mahasiswa SI PG-PAUD. Tujuan penelitian ini adalah untuk mengetahui pendapat mahasiswa Semester $\mathrm{V}$ terhadap perkuliahan daring dan apa faktor pendukung dan penghambat yang dihadapi mahasiswa. Penelitian ini menggunakan pendekatan kualitatif dengan jenis penelitian field research, Adapun yang menjadi populasi yang peneliti ambil adalah mahasiswa semester $\mathrm{V}$ dengan teknik purposive sampling, sementara teknik pengumpulan data yang digunakan adalah observasi, wawancara dan dolumentasi, model analisis data yang digunakan adalah model Miles dan Huberman yaitu dilakukan secara interaktif dan berlangsung secara terus menerus sampai tuntas, meliputi data reduction, data display, conclusion. Disimpulkan bahwa dalam pelaksanaan perkuliahan daring mahasiswa semester $\mathrm{V}$ terpecah menjadi 2 kubu pro dengan alasan lebih banyak waktu bisa mengerjakan pekerjaan lain adapun kubu kontra dengan alasan perkuliahan kurang efektif dan efesien, untuk kelebihan sepakat dengan perkuliahan dapat dilakukan dari rumah masing, dan kekurangan masih terkendala sinyal yang kurang bagus, untuk nilai (IPK) mayoritas meningkat dari IPK semester sebelumnya.
\end{abstract}

\section{Kata Kunci: Perkuliahan Daring}

Abstract

The change in the lecture system from face-to-face to online due to the emergence of the Covid-19 outbreak has more or less influenced the way students learn for SI PG-PAUD. The purpose of this study was to find out the opinion of Semester $V$ students towards online lectures and what are the supporting and inhibiting factors faced by students. This study uses a qualitative approach with the type of field research. The population that the researcher takes is the fifth semester students with purposive sampling technique, while the data collection techniques used are observation, interviews and documentation, the data analysis model used is the Miles and Huberman model. which is carried out interactively and takes place continuously until complete, including data reduction, data display, conclusion. It was concluded that in the implementation of online lectures, the fifth semester students were divided into 2 pro camps on the grounds that more time could be done for other work, while the cons were on the grounds that lectures were less effective and efficient, for the advantages of agreeing that lectures could be carried out from home, and the disadvantages 
were still constrained by signals. which is not good, for the value (GPA) the majority increased from the previous semester's GPA.

\section{Keywords: Online Lessons}

\section{PENDAHULUAN}

Indonesia pertama kali mengkonfirmasi kasus Corona Virus Disease (COVID-19) pada Senin 2 Maret lalu. Saat itu, Presiden Joko Widodo (Jokowi) mengumumkan ada dua orang Indonesia positif terjangkit virus Corona yakni perempuan berusia 31 tahun dan ibu berusia 64 tahun.

Kasus pertama tersebut diduga berawal dari pertemuan perempuan 31 tahun itu dengan WN Jepang yang masuk ke wilayah Indonesia. Pertemuan terjadi di sebuah klub dansa di Jakarta pada 14 Februari. Saat itu setidaknya sudah ada 50 negara yang sudah mengkonfirmasi memiliki kasus COVID-19. China sendiri melaporkan ke WHO mengenai adanya beberapa kasus pneumonia aneh di Wuhan pada Desember 2019.

Informasi di atas langsung menjadi informasi yang paling dicari-cari oleh warganet atau netizen, informasinya jadi viral meskipun pada awalnya COVID-19 menyerang 2 orang warga Depok, Provinsi Jawa Barat Indonesia, namun saat ini kasus COVID-19 sudah terjadi merata semua provinsi yang ada di Indonerisa bahwa tidak ada Kabupaten yang luput dari paparan kasus COVID-19 ini.

Di awal kemunculan COVID-19 semuanya masih berjalan lancar seakan tidak terjadi apa-apa, lamun lambat laun wabah COVID-19 menjadi yang paling cepat penyebarannya, bahwak tidak begitu lama wabah COVID-19 dinyatakan sebagai pandemic COVID-19 oleh Word Health Organization (WHO) tepatnya pada tanggal 11 Maret 2020.

COVID-19 tidak hanya mengganggu ekonomi bangsa tapi juga menganggu proses pendidikan yang kala itu akan menghadapi Ujian Nasional (UN), Pada hari Senin, 16 Maret 2020 KEMENDIKANAS mengeluarkan kebijakan meliburkan proses perkuliahan tatap muka yang digantikan dengan system perkuliahan daring System untuk semua jenjang pendidikan hal ini dilakukan untuk memutus mata rantai penyebaran COVID-19 yang memawab saat ini [daring] tersedia dalam; https://bdkjakarta.kemenag.go.id/berita/efektivitas-perkuliahan-daring-di-masapandemi-covid-19 [diakses pada tanggal 13 September 2020).

Proses perubahan perkuliahan ini juga yang diikuti oleh Program Studi SI Pendidikan Guru Pendidikan Anak Usia Dini (PG-PAUD) Fakultas IImu Pendidikan, Universitas Pahlawan Tuanku Tambusai, mulai mengikuti perubahan proses perkuliahn tatap muka menjadi daring System.

Memang sebetulnya perkuliahan daring system sudah mulai diterapkan di Universitas Pahlawan Tuanku Tambusai tetapi tidak 100\% dengan adanya COVID-19 ini secara otomatis perkuliahan diarahkan lebihnya banyak dengan system daring yang paling tidak $50 \%$ luring dan $50 \%$ secara daring

Mahasiswa SI PG-PAUD yang berjumlah 11 mahasiswa yang juga ikut menerapkan proses perkuliahan daring, Ini yang menarik perhatian peneliti untuk 
melakukan penelitian secara mendalam mengenai "Analisis Perkuliahan Daring Pada Semester V Program Studi Pendidikan Guru Pendidikan Anak Usia Dini, Tahun Akademik 2020-2021".

\section{METODE}

Penelitian ini bersifat deskriptif artinya penelitian yang menggambarkan atau memaparkan objek tertentu dengan kata-kata secara jelas dan terperinci dengan penelitian yang penulis lakukan, Suryabrata (2010:147). Penelitian ini ditunjukan untuk mendeskripsikan fenomena-fenomena yang ada, baik fenomena alamiah maupun fenomena buatan manusia. Fenomena itu bisa berupa bentuk, aktivitas, perubahan, hubungan, kesamaan, dan perubahan antara fenomena yang satu dengan fenomena yang lainnya. Jadi penelitian deskriptif selain menggambarkan kejadian yang terjadi dalam masyarakat juga mengungkapkan data yang ada padanya dan juga memberikan analisis untuk memperoleh kejelasan dan kebenaran masalah yang dihadapi.

Dalam hal ini penulis hanya mengungkapkan sesuai dengan apa adanya, guna memberikan penjelasan dan jawaban terhadap pokok yang di teliti yaitu dapat mengetahui pelaksanan, faktor pendukung dan penghambat dalam pelaksanaan pembelajaran daring

Adapun teknik yang digunakan dalam penelitian ini adalah teknik non random sampling, artinya tidak semua individu di dalam populasi diberikan hak yang sama untuk dijadikan anggota sample. Teknik non random sampling berjenis purposive sampling yaitu sekelompok anggota sample yang mempunyai karakteristik yang sesuai dengan karakteristik populasi yang terlebih dahulu telah diketahui. Berdasarkan pendapat di atas kriteria untuk menjadi sampel dalam penelitian ini adalah :

1) Masiswa Semester 5 Prodi SI PG-PAUD, Fakultas IImu Pendidikan, Universitas Pahlawan Tuanku Tambusai

2) Dosen yang mengajar pada semester 5 Prodi SI PG-PAUD, Fakultas Ilmu Pendidikan,

Keseluruhan sample dari kriteria yang telah disebutkan di atas maka penulis mendapatkan sample sebanyak 16 Masiswa Semester 5 Prodi SI PG-PAUD, Fakultas IImu Pendidikan, Universitas Pahlawan Tuanku Tambusai

\section{HASIL PEMBAHASAN}

\section{Hasil}

Wawancara dilakukan kepada mahasiswa semester V Prodi S1 PG-PAUD Fakultas Ilmu Pendidikan Universitas Pahlawan Tuanku Tambusai, yang dilaksanakan bulan Oktober 2020, wawancara pertama dengan Informan (I.1) hasil wawancara:

"Perkenalkan Nama Saya Widya Ayu Kusuma. Saya Kurang Menyukai Perkuliahan ini Karena banyak kendala yang terjadi. Kekurangan dalam kuliah daring /online ini adalah Masalah Jaringan dan Kurangnya komunikasi yang baik selama proses Belajar dan Pembelajaran. Selain itu masalah Waktu dalam jadwal Perkuliahan 
daring/online yang kurang tepat. Untuk kelebihannya saya tidak perlu kekampus yang cukup jauh dan cukup membutuhkan waktu yang lama. Nilai saya naik dari mapel semester sebelumnya akan tetapi Nilai saya juga ada yang sedikit berkurang disalah satu mapel dari semester sebelumnya, IPK naik"

Dari wawancara tersebut di atas diketahui jika informan yang bersangkutan tidak menyukai pelaksanaan perkuliahan daring, karena terkendala jaringan (signal provider), kemudian komunkasi yang kurang berjalan dengan baik, masih terjadi komunkasi satu arah saja, Selain itu masalah Waktu dalam jadwal Perkuliahan daring/online yang kurang tepat. Untuk kelebihan perkuliahan daring tidak perlu kekampus yang cukup jauh dan cukup membutuhkan waktu yang lama, adapun nilai mata kuliah naik dari nilai mata kuliah semester sebelumnya akan tetapi ada nilainya yang turun di salah satu mata kuliah dari semester sebelumnya

Selanjutnya wawancara dengan informan 2 (I.2) dengan hasil wawancara sebagai berikut:

"Perkenalkan nama saya Nury Hasdar Putri. Saya pribadi kurang menyukai perkuliahan daring yang terjadi karena, menurut saya pembelajaran dan perkuliahan menjadi tidak efektif. kendala yang sering terjadi pada saat daring dirumah ialah jaringan yang sulit dan bergantung pada hidup matinya listrik, seketika listrik dirumah sedang mati, jaringan juga otomatis hilang, dan ini sangat sulit dalam mengikuti perkuliahan daring. Ada juga kelebihan dalam daring ini, dengan kuliah di rumah, kita dapat memanfaatkan waktu lebih banyak untuk membantu orang tua, serta dapat menghemat untuk uang makan jika berada di asrama. Nilai di semester ini selama daring, tetap sama dengan nilai sebelumnya ketika masih kuliah dengan sistem offline, IPK tetap"

Diperoleh data dari wawancara di atas bahwa informan I.2 kurang menyukai perkuliahan daring yang terjadi karena menurut informan yang bersangkutan pembelajaran dan perkuliahan daring menjadi tidak efektif. kendala yang sering terjadi ialah jaringan yang sulit dan bergantung pada hidup matinya listrik. Ada juga kelebihan dalam daring ini, dengan kuliah di rumah, kita dapat memanfaatkan waktu lebih banyak untuk membantu orang tua, serta dapat menghemat untuk uang makan jika berada di asrama. Nilai di semester ini selama daring, tetap sama dengan nilai sebelumnya ketika masih kuliah dengan sistem offline

Wawacara berikutnya dengan informan (I.3) dengan petikan wawancara sebagai berikut:

"Perkenalkan nama saya hikma novita, mengenai perkuliahan daring saya sangat kurang menyukai online,karena masalah terutama kendala dengan jaringan dan kouta nya terbatas. Dan perkuliahan tatap muka tidak efektif jadinya. Kelebihan kuliah online yaitu semua perkerjaan dirumah bisa terkendali dan bisa membantu ibu dirumah. Nilai mata kuliah saya disemester ini naik sedikit dari nilai saya disemester yg lalu, IPK saya naik" 
Dari wawancara di atas diperoleh fakta bahwa informan yang bengsangkutan tidak menyukai perkuliahan online atau daring, hal ini dikarena terkendala dengan jaringan dan kouta nya terbatas, dan perkuliahan tidak efektif. Kelebihan kuliah online yaitu semua perkerjaan dirumah bisa terkendali dan bisa membantu ibu dirumah. Adapun nilai mata kuliah di semester ini naik sedikit dari nilai di semester yg lalu

Wawancara berikutnya dengan informan (I.4), berikut petikan wawancara yang diperoleh:

"Nama saya insaniati, mengenai perkuliahan dari saya kurang menyukainya, alasannya proses pembelajaran menjadi kurang efektif, efisien, kurang menarik, dan kurang interaktif, serta kurang nya etika dalam berjumpa. Adapun kendala nya adalah dana kuota yang tidak optimal, dan jaringan yang harus disesuaikan dengan kondisi nya. Apalagi untuk daerah yang jauh dari perkotaan. Dan hal itu sangat mengganggu bagi diri saya pribadi. Kelebihannya hanyalah kita tidak perlu pergi ke kampus, sangat bagus bagi mahasiswa yang lokasi rumahnya berjauhan dengan kampus. Nilai mata pelajaran saya ada stabil dan ada yang menurun, akan tetapi IPK tetap. Dikarenakan dalam pemakaian komputer saya kurang teliti, jika saja ujian matkul berupa tulisan saya sudah pasti bisa melihat keseluruhan soalnya. Saya sangat berharap kondisi akan mulai terus membaik agar pembelajaran juga lebih baik dibanding tahun sebelumnya. Mahasiswa dapat berinteraksi lebih baik dengan dosennya, serta dengan diberlakukannya kembali PTM, maka pembelajaran yang kurang dipahami dapat di tanggapi dan dijelaskan kembali"

Dari wawancara di atas diperoleh fakta bahwa informan (I.4) kurang menyukai perkuliahan daring, alasannya proses pembelajaran kurang efektif, efisien, kurang menarik, dan kurang interaktif, serta kurangnya etika dalam berjumpa. Adapun kendala nya adalah dana kuota yang tidak optimal, dan jaringan yang harus disesuaikan dengan kondisi nya. Apalagi untuk daerah yang jauh dari perkotaan. Dan hal itu sangat mengganggu bagi informan tersebut secara pribadi. Kelebihannya yang bersangkutan tidak perlu pergi ke kampus, sangat bagus bagi mahasiswa yang lokasi rumahnya berjauhan dengan kampus. Nilai mata kuliah yang diperoleh lebih ke stabil dan ada juga yang menurun hal ini dikarenakan dalam pemakaian komputer yang bersangkutan kurang teliti. Informan sangat berharap kondisi akan mulai terus membaik agar perkuliahan juga lebih baik dibanding tahun sebelumnya. Mahasiswa dapat berinteraksi lebih baik dengan dosennya, serta dengan diberlakukannya kembali perkuliahan tatap muka (PTM), maka pembelajaran yang kurang dipahami dapat di tanggapi dan dijelaskan kembali

Wawancara selanjutnya dengan informan (I.5) berikut petikan wawancara tersebut;

"Nama saya Putri Awalia, saya kurang menyukai perkuliahan secara online, karna tentu tidak efektif dalam penyerapan materinya, saya lebih dominan jika di kampus. Tapi di mata kuliah tertentu saya masih bisa memahami pelajaran yg di sampaikan walaupun secara daring. Kendala saat kelas online pastinya kondisi sinyal \& jaringan yg kadang 
blank. Banyak kesalahan dari sistem juga yg menyulitkan, di beberapa apk belajar yg bjsa merugikan proses belajar saya. Kelebihan dari sistem daring ini saya punya waktu luang yg bisa di isi dgn kegiatan dan keperluan lain. Menghemat waktu dan tenaga, Dan lebih nyaman karna di lakukan di rumah. Semester ini nilai saya masih stabil dan perubahan nya di beberapa mata kuliah dan signifikan, IPK naik"

Dari wawancara di atas diperoleh fakta bahwa informan (I.5) kurang menyukai perkuliahan secara online, karna tidak efektif dalam penyerapan materinya. Meskipun pada mata kuliah tertentu informan masih bisa memahami perkuliahan yang disampaikan walaupun secara daring. Kendala yang dihadapi adalah kondisi sinyal. Kelebihan dari sistem daring menurut informan adalah punya waktu luang yg bisa di isi dengan kegiatan dan keperluan lain, menghemat waktu dan tenaga, dan lebih nyaman karna di lakukan di rumah. Semester ini nilai informan masih stabil dan perubahannya di beberapa mata kuliah tidak terlalu signifikan

Berikutnya wawancara dengan informan (I.6) adapun petikan wawancara sebagai berikut"

"Perkenalkan nama saya rina husnul khotima, mengenai perkuliahan daring saya sangat menyukai online, karena saya bisa bekerja diselah kuliah online. Kelebihan kuliah online yaitu semua pekerjaan dirumah bisa terkendali dan juga bisa bekerja diselah kuliah Nilai mata kuliah naik sedikit dari nilai semester kemaren, IPK saya naik"

Diperoleh fakta dari wawancara di atas adalah informan menyukai proses perkuliahan daring, alasan yang dimukakan lebih ke alasan ekonomi, informan menyatakan bahwa informan bisa bekerja di sela perkuliahan online, Kelebihan kuliah online yaitu semua pekerjaan di rumah bisa terkendali dan juga bisa bekerja di sela perkuliahan online, adapun nilai mata kuliah naik sedikit dari nilai semester kemaren

Berikutnya wawancara dengan informan (I.7) adapun petikan wawancara sebagai berikut:

"Nama saya hartatik, saya menyukai perkuliahan daring/online,karena saya bisa mengerjakan pekerjaan rumah dan mengurus anak- anak diselah kuliah online. Kendala saat perkulihan online yaitu sinyal dan jaringan yg kurang mendukung. Kelebihan kuliah online yaitu semua pekerjaan di rumah bisa terselesaikan,punya waktu untuk mengurus anak - anak serta menghemat waktu dan tenaga karena dilakukan di rumah. Nilai saya di semester ini alhamdulillah naik dari semester sebelumnya, IPK naik"

Fakta yang diperoleh dari wawancara di atas adalah informan menyukai perkuliahan daring/online, karena informan yang bersangkutan bisa mengerjakan pekerjaan rumah dan mengurus anak- anak diselah kuliah online. Kendala saat perkulihan online yaitu sinyal kurang mendukung. Kelebihan kuliah online yaitu semua pekerjaan di rumah bisa terselesaikan,punya waktu untuk mengurus anak-anak serta menghemat waktu dan tenaga karena dilakukan di rumah. Nilai informan di semester ini naik dari semester sebelumnya

Berikutnya wawancara dengan informan (I.8) adapun petikan wawancara sebagai berikut: 
"Nama saya Eva Sylpidalena, saya menyukai perkuliahan daring/online,karena saya bisa mengerjakan pekerjaan rumah dan mengurus anak- anak serta keluarga setelah kuliah online. Kendala saat perkulihan online yaitu sinyal dan jaringan yg kurang mendukung. Kelebihan kuliah online yaitu semua pekerjaan di rumah bisa terselesaikan,punya waktu untuk mengurus anak- anak serta menghemat waktu dan tenaga karena dilakukan di rumah. Nilai saya di semester ini alhamdulillah tetap dari semester sebelumnya, dan IPK naik"

Fakta yang diperoleh dari wawancara di atas adalah informan menyukai perkuliahan daring/online, karena informan yang bersangkutan bisa mengerjakan pekerjaan rumah dan mengurus anak- anak diselah kuliah online. Kendala saat perkulihan online yaitu sinyal kurang mendukung. Kelebihan kuliah online yaitu semua pekerjaan di rumah bisa terselesaikan, punya waktu untuk mengurus anak-anak serta menghemat waktu dan tenaga karena dilakukan di rumah. Nilai informan di semester ini tetap atau stabil dari semester sebelumnya

Berikutnya wawancara dengan informan (I.9) adapun petikan wawancara sebagai berikut:

"Perkenalkan nama saya Resti indriani saya lebih menyukai perkuliahan daring/ online karena saya bisa bekerja diselah kuliah online, dan juga saya merasa aman karena jarak kampus dari rumah yg cukup jauh, dan harus berulang setiap hari membuat saya sedikit takut, jdi saya lebih suka online. Kelebihan kuliah online menurut saya yaitu dengan kuliah online saya bisa melaksanakan kuliah sambil bekerja, Nilai mata kuliah saya naik dari nilai semester kemare, IPK naik"

Dari wawancara di atas diperoleh fakta bahwa informan (I.9) menyukai perkuliahan daring karena yang bersangkutan bisa bekerja di sela perkuliahan online, dan juga informan merasa aman karena jarak kampus dari rumah yang cukup jauh, dan harus berulang setiap hari yang membuat informan sedikit takut, dengan begitu informan lebih menyukai perkuliahan online. Kelebihan perkuliahan online menurut informan yaitu dengan perkuliahan online informan bisa melaksanakan kuliah sambil bekerja, nilai mata kuliah informan naik dari nilai semester sebelumnya

\section{PEMBAHASAN}

Pembahasan dan anlisis dalam penelitian ini lebih berfokus pada hasil wawancara yang telah dilakukan pada bulan Oktober 2020

1. Dalam pelaksanaan perkuliahan daring mahasiswa semester V SI PG-PAUD Fakutas IImu Pendidikan, Universitas Pahlawan Tuanku Tambusai terpecah menjadi 2 kubu pro dan kontra atau kubu yang menyukai dan kubu yang tidak menyukai perkuliahan daring

Kubu yang menyukai perkuliahan daring jika diamati dari hasil wawancara bersama informan adalah meraka yang sudah berkeluarga (ibu rumah tangga) sehingga perkuliahan daring memberikan keleluasan bagi meraka dalam menjalankan fungsi sebagai ibu rumah tangga yaitu mengasuk anak, dan mengerjakan pekerjaan rumah tangga, alasan lain yang menyukai perkuliahan daring adalah mereka dapat bekerja di sela perkuliahan daring 
dari komunikasi lanjutan diketahui bahwa mereka adalah mahasiswi yang memilik perkaan lain selain kuliah (menjaga toko), ada juga yang beralasan menyukai perkuliahan dari karena lokasi rumah kampus yang jauh sehingga menghawatirkan jika harus pulang pergi ke kampus universitas pahlawan

Kubu yang tidak menyukai perkuliahan daring beralasan bahwa perkuliahan tidak efektif jika dilakukan secara daring, pemahaman materi selama perkuliahan secara daring tidak diperoleh secara utuh, komunkasi tidak terbangun dengan baik selama perkuliahan daring

2. Kelebihan perkuliah daring

Faktor kelebiahn yang sering kali disampaikan oleh informan saat wawancara dan hampir semuanya sepakat jika pembelajaran daring mudah dilaksanakan, hanya menunggu informasi perkuliahan dari dosen pengampu atau penanggun jawab (PJ) mata kuliah, perkuliahan pun sudah dapat dimulai, mahasiswa dapat mengikuti pembelajaran daring dari rumah, ini juga sebagai penghematan karena tidak perlu mengeluarkan uang transportasi, berikut waktu yang ada bisa digunakan untuk membantu pekerjaan orang tua dirumah, atau mengerjakan pekerjaan rumah tangga bagi mereka yang sudah menjadi ibu rumah tangga, atau bekerja bagi mahasiswa yang memiliki pekerkaan sampingan seperti menjaga toko dan lainnya

3. Kekurangan perkuliahan daring

Signal kurang bagus/jaringan kurang stabil adalah alasan yang sering kali dijadikan jawaban wawancara yang diberikan informan, tentunya Sukses pembelajaran daring tentu sangat tergantung dengan bagusnya signal, signal yang kurang bagus atau jaringan yang kurang stabil tentu sangat menggangu proses pembelajaran daring itu sendiri, masalah ini sebenarnya bukan masalah yang bisa kita atasi sendiri karena terkait dengan layanan provider apakah sudah menjangkau atau belum? Apakah jangkauannya kuat atau tidak? Karena bisa jadi menjangkau tapi tidak kuat karena kontur lokasi dimana mahasiswa mengakses, kemudian faktor cuaca juga mempengaruhi, atau pengaruh arus listrik

Masalah jaringan adalah masalah yang susah diuraikan bagi orang awan akan tetapi ada hal lain yang menurut peneliti dapat dilakukan untuk menghindari gangguan signal saat daring yaitu mencari lokasi-lokasi yang sekirangnya signal stabil, sehingga mengikuti perkuliahan daring tidak terganggu

Kuota yang terbatas juga menjadi kendala dalam perkuliahan daring hal ini dikarenakan ketiadaan dana yang tesedia (tidak memilik uang untuk membeli pulas) meskipun tidak banyak informan yang menjadikan ini sebagai kekurang dalam perkuliahan daring

4. Nilai mata kuliah selama perkuliahan daring

Meskipun dalam pelaksanaan perkuliahan daring terjadi pro dan kontra dengan berbagai alasan yang dikemukan, akan tetapi untuk perolehan nilai mata kuliah lebih banyak informan yang mengungkapkan bawah nailainya (IPK) lebih meningkat dari peroleh IPK dari semester sebelumnya dimana perkuliahan masih menggunakan sistem perkuliahan tatap muka, meskipun adapun yang meningkatkan stabil/sama 


\section{KESIMPULAN}

Dari pembahasan sebelumnya dapat disimpulkan bahwa dalam pelaksanaan perkuliahan daring mahasiswa semester V SI PG-PAUD Fakutas IImu Pendidikan, Universitas Pahlawan Tuanku Tambusai terpecah menjadi 2 kubu pro dengan alasan lebih banyak waktu bisa mengerjakan pekerjaan lain adapun kubu kontra dengan alasan perkuliahan kurang efektif dan efesien, untuk kelebihan sepakat dengan perkuliahan dapat dilakukan dari rumah masing, dan kekurangan masih terkendala sinyal yang kurang bagus, untuk nilai (IPK) mayoritas meningkat dari IPK semester sebelumnya

\section{DAFTAR PUSTAKA}

Arikunto, S. (2013). Prosedur Peneitian Suatu Pendekatan Praktek. Jakarta:Rineka Cipta

Aunurrahman. (2009). Belajar dan Pembelajaran. Bandung: Alfabeta

Bachtiar, W. (1997). Metodologi Penelitian IImu Dakwah. Jakarta: logos

Baharuddin. (2010). Teori Belajar dan Pembelajaran. Jogjakarta: Arruz Media

Bungin, B. (2010). Metodologi Penelitian Kualitatif, Cet.10. Jakarta:Rajawali Pers

Gunawan, I. (2016). Metode Penelitian Kualitatif Teori \& Praktik.Jakarta: Bumi Aksara

Kosmiyah, I. (2012). Belajar dan Pembelajaran. Yogyakarta: Teras

Moleong, L.J. (2013). Metode Penelitian Kualitatif. Bandung : PT. Remaja Roesdarkarya,

Molinda. M. (2005). Instrucsional Technology and Media for Learning. New Jersey; Colombus press

Mutadi. (2007). Pendekatan Efektif dalam Pembelajaran. Semarang; Balai Diklat

Narbuko. C dan Achmadi, A. (2015). Metodologi Penelitian, Cet.14. Jakarta:Bumi Aksara

Nasution, S. (2006). Metode Reseacrh. Jakarta : Bumi Aksara

Sedarmayati dan Hidayat (2002). Metodologi Penelitian. Bandung: Mandar Maju

Slameto. (2010). Belajar dan Faktor-faktor yang Mempengaruhinya. Jakarta: PT. Rineka Cipta

Sukiman. (2010. Pengembangan Media Pembelajaran. Jogjakarta: Pedagogia

Suryabrata, S. (2010). Metodologi Penelitian. Jakarta: Rajawali Pers

Trianto. (2009). Mendesain Model Pembelajaran Inovatif-Progresif. Jakarta: Kencana

Zulkifli. (2012). Pengertian Mobile Learning. [online]. Tersedia: http://blogzulkifli.wordpress.com/2012/01/21/pengertian-mobilelearning/\#comments. [diakses pada 13 September 2020] 
[online] tersedia dalam; https://bdkjakarta.kemenag.go.id/berita/efektivitaspembelajaran-daring-di-masa-pandemi-covid-19 [diakses pada tanggal 13 September 2020). 